\title{
PEMANFAATAN MEDIA SOSIAL FACEBOOK UNTUK MENILAI SIKAP ILMIAH (AFEKTIF) MAHASISWA
}

\author{
Ngurah Mahendra Dinatha, S.Pd., M.Si \\ STKIP CitraBakti, NusaTenggaraTimur, Indonesia \\ ngurahm87@gmail.com
}

\begin{abstract}
Abstrak
Penelitian ini bertujuan untuk mengetahui pemanfaatan media sosial facebook untuk menilai sikap ilmiah (afektif) mahasiswa pada mata kuliah praktikum sains inovatif di STKIP Citra Bakti Ngada. Penelitian ini merupakan penelitian kualitatif deskriptif. Teknik sampling yang digunakan adalah simple random sampling untuk menentukan jumlah sampel yang diteliti. Penelitian dilaksanakan di STKIP Citra Bakti, Kabupaten Ngada, NTT. Jumlah subjek penelitian adalah 40 orang. Pengumpulan data pemanfaatan media sosial facebook untuk mengukur sikap ilmiah menggunakan kuesioner dan wawancara. Data dianalisis secara deskriptif dengan mengacu pada skala teoretik. Dari hasil penelitian diperoleh data yaitu sebanyak 35 orang mahasiswa atau sebesar $87,5 \%$ dari jumlah seluruh mahasiswa dapat dinilai sikap ilmiahnya
\end{abstract}

Kata kunci: Penilaian sikap, facebook, praktikum sains inovatif

Keywords: inquiry, natural science learning

\begin{abstract}
This present study aims to assess students' scientific attitude (affective aspect) from the utilization of facebook upon college students of STKIP Citra BaktiNgada on innovative science practice class. This present study employs a descriptive qualitative design. Further, the subjects are selected through simple random sampling which results in 40 students. Moreover, the measurement of students' scientific attitude from the utilization of facebook as a media was based on the result of questionnaire and interview. The data is presented descriptively by referring to theoretic scale. From the study, it is obtained that there are 35 students or $87,5 \%$ from all subjects which its scientific attitude can be assessed thoroughly.
\end{abstract}

Keyword: Attitude Assessment, facebook, innovative science practice

\section{Pendahuluan}

Sejalan dengan perkembangan ilmu pengetahuan dan teknologi, dunia pendidikan juga mengalami perkembangan yang cukup pesat. Banyak upaya yang telah ditempuh pemerintah pusat maupun pemerintah daerah untuk meningkatkan SDM melalui peningkatan mutu pendidikan, diantaranya meningkatkan kualitas tenaga pendidikan melalui pendidikan dan pelatihan. Selain bertugas untuk mendidik, dosen juga mempunyai kewajiban untuk menilai mahasiswa secara menyeluruh yaitu dengan penilaian kognitif, afektif, dan psikomotor. Penilaian kognitif adalah penilaian yang mencakup kegiatan mental (otak). Menurut Bloom, segala upaya yang menyangkut aktivitas otak adalah termasuk dalam ranah kognitif. Ranah kognitif berhubungan dengan kemampuan berfikir, termasuk didalamnya kemampuan menghafal, memahami, mengaplikasi, menganalisis, mensintesis, dan kemampuan mengevaluasi. Penilaian afektif adalah penilaian watak perilaku seperti sikap, minat, konsep diri, nilai dan moral. Penilaian psikomotor adalah penilaian hasil belajar yang pencapaiannya melalui keterampilan manipulasi yang melibatkan otot dan kekuatan fisik. Ketiga aspek penilaian tersebut mempunyai kesulitan yang berbeda beda dalam penerapannya, terutama penilaian afektif (sikap).

Menurut Popham (1995), ranah afektif menentukan keberhasilan belajar seseorang. Orang yang tidak memiliki minat pada pelajaran tertentu sulit untuk mencapai keberhasilan belajar secara optimal. Seseorang yang berminat dalam suatu mata pelajaran diharapkan akan mencapai hasil pembelajaran yang optimal. Oleh karena itu semua pendidik harus mampu membangkitkan minat semua peserta didik untuk mencapai kompetensi yang telah ditentukan. Selain itu ikatan emosional sering diperlukan untuk membangun semangat kebersamaan, semangat persatuan, semangat nasionalisme, rasa sosial, dan sebagainya. Untuk itu semua dalam merancang program pembelajaran, satuan pendidikan harus memperhatikan ranah afektif.

Pada mata kuliah Praktikum Sains Inovatif di STKIP Citra Bakti Ngada, penilaian hanya dilihat dari penilaian produk atau hasil belajar juga penilaian proses belajar. Pada perkuliahan tersebut umumnya penilaian produk atau hasil belajar lebih difokuskan untuk menilai aspek kognitif saja. Prestasi hasil belajar kognitif yang didukung oleh sikap dan perilaku yang baik perlu diupayakan. Oleh karena itu, secara bertahap perlu dilakukan pengukuran hasil belajar dalam aspek sikap. 
Kompetensi sains harus diarahkan salah satunya untuk menjamin pertumbuhan kemampuan bekerja dan sikap ilmiah (Depdiknas, 2008). Sikap ilmiah adalah salah satu faktor yang perlu dipertimbangkan dalam proses pembelajaran untuk meningkatkan prestasi belajar. Oleh karena itu, sikap ilmiah perlu dinilai untuk memberikan feedback (umpan balik) terhadap mahasiswa sehingga dengan bimbingan dosen dapat menanamkan dan menumbuhkan sikap ilmiah dalam dirinya. Sikap ilmiah yang harus dimiliki oleh mahasiswa antara lain memiliki rasa ingin tahu atau kuriositas yang tinggi dan kemampuan belajar yang besar, tidak dapat menerima kebenaran tanpa bukti, jujur, terbuka, toleran, skeptik, optimis, pemberani, kreatif atau swadaya.

Menurut Rustaman (2003) penilaian atau pengukuran hasil belajar dapat dilakukan secara tertulis, lisan, atau pun melalui observasi. Menulis laporan praktikum adalah salah satu cara yang dapat digunakan untuk mengevaluasi kegiatan praktikum. Selama ini laporan praktikum hanya dimanfaatkan untuk menilai aspek kognitif saja, misalnya dengan melihat ketepatan atau pun kedalaman pembahasan yang ditulis mahasiswa. Padahal melalui laporan praktikum, sikap ilmiah mahasiswa pun dapat dinilai, misalnya aspek kejujuran, disiplin, kecermatan juga kerja keras. Hal ini sesuai dengan pernyataan Rustaman (2003) bahwa prosedur tertulis dapat dilakukan untuk mengukur hasil belajar yang sifatnya kognitif dan afektif.

Pengukuran aspek afektif (sikap) khususnya sikap ilmiah biasa dilakukan melalui skala sikap. Namun, penyusunan skala sikap sebagai instrumen pengukuran sikap individu ataupun sikap kelompok bukanlah hal yang mudah (Azwar, 2009). Skala sikap ini sulit untuk disusun dan diaplikasikan oleh dosen di dalam perkuliahan Praktikum Sains Inovatif.

Penilaian tidak hanya dilakukan oleh dosen saja, melainkan mahasiswa pun dapat dilibatkan dalam proses penilaian dengan tujuan untuk memperbaiki kualitas belajar (Bostock dalam Susianna, 2008). Salah satu cara adalah dengan menggunakan peer assessment yaitu sebuah proses di mana seorang pelajar menilai hasil belajar teman atau pelajar lainnya yang berada pada level yang sama. Maksud dari level yang sama adalah jika dua orang atau lebih berada dalam level kelas yang sama atau subjek pelajaran yang sama. Beberapa kendala dari penggunaan peer assessment, diantaranya yaitu membutuhkan waktu yang lama mulai dari sosialisasi dan penyepakatan rubrik sampai proses pelaksanaan dan umpan balik, hal ini akan berpengaruh terhadap efektivitas tenaga, waktu dan biaya yang digunakan untuk menilai sikap dari masing-masing mahasiswa.

Salah satu cara untuk menanggulangi masalah tersebut adalah dengan memanfaatkan jaringan internet dan juga media sosial. Karena dilihat dari intensitas penggunakan internet dan juga media sosial khususnya mahasiswa di STKIP Citra Bakti sangat tinggi, hal ini di dukung adanya jaringan internet yang memadai yaitu sudah menggunakan FO (Fiber Optic). Salah satu media sosial yang digunakan adalah facebook. Media sosial inidapat kita manfaatkan untuk mengatasi masalah dalam dunia pendidikan, khususnya dalam hal penilaian (peer assessment). Kegiatan peer assessment yang dilakukan mahasiswa secara online dengan memanfaatkan jejaring facebook bisa menjadi jembatan untuk permasalahan kebutuhan waktu yang biasanya melewati alokasi waktu yang telah disediakan ketika melakukan peer assessment konvensional. Selain itu, pemanfaatan jejaring facebook dalam penggunaan peer assessment online ini akan menghemat biaya karena setiap mahasiswa bisa memiliki akun facebook secara gratis, seluruh rubrik maupun hasil kerja mahasiswa berupa laporan praktikum tidak perlu dicetak, cukup dikirim (upload) saja melalui facebook notes, sedangkan untuk penilaian akan dikirimkan melalui facebook message untuk menjaga kerahasiaan. Hal ini selain menghemat biaya juga akan memudahkan dalam pengarsipan. Dengan demikian, jejaring facebook dapat dijadikan solusi yang murah dan mudah untuk digunakan dalam menilai hasil kerja mahasiswa melalui peer assessment.

Atas dasar latar belakang yang telah diuraikan di atas maka dilakukan penelitian untuk memperoleh informasi mengenai pemanfaatan jejaring facebook untuk menilai sikap ilmiah mahasiswa pada hasil kerja praktikum mata kuliah praktikum sains dasar inovatif di STKIP Citra Bakti Ngada.

\section{Metode Penelitian}

Penelitian ini adalah penelitian deskriptif, yaitu penelitian untuk memberikan uraian mengenai gejala, fenomena, atau fakta yang diteliti dengan mendeskripsikan tentang variabel mandiri, tanpa bermaksud menghubungkan atau membandingkan. Penelitian ini berusaha mendeskripsikan variabel berdasarkan indikator dan deskriptor dari variabel penelitian (Musfiqon, 2012). Penelitian ini mengungkap pemanfaatan facebook untuk menilai sikap ilmiah (afektif) mahasiswa pada mata kuliah praktikum sains inovatif. Penelitian dilakukan di STKIP Citra Bakti, Kabupaten Ngada, NTT.

Populasi yang digunakan dalam penelitian ini adalah mahasiswa semester 6 yang mengambil mata kuliah Praktikum Sains Inovatif pada Tahun Akademik 2016/2017 sebanyak 80 orang.Sampel dalam penelitian ini sebanyak 40 orang. Sampel diambil dengan menggunakan teknik purposive sampling. Teknik purposive sampling dilakukan berdasarkan pertimbangan yang sesuai dengan maksud dan tujuan penelitian (Soehartono, 2000). Pertimbangan memilih 40 orang mahasiswa karena berdasarkan angket pendahuluan yang disebarkan dapat diketahui bahwa tidak semua mahasiswa di kelas tersebut memiliki akun facebook, sehingga dipilihlah 40 orang mahasiswa yang mempunyai akun facebook, hal ini bertujuan agar tidak menyulitkan ketika melakukan penelitian. 
Untuk mengetahui pemanfaatan facebookuntuk menilai sikap ilmiah (afektif) mahasiswa pada mata kuliah praktikum sains inovatif maka peneliti melakukan penelitian ini dengan menggunakan dua teknik pengumpulan data yaitu berupa kuesioner atau angket dan juga wawancara.

Peer assessment online didefinisikan sebagai kegiatan saling menilai di antara mahasiswa dalam satu kelompok praktikum melalui jejaring facebook tentang sikap ilmiah mahasiswa pada hasil kerja praktikum fotosintesis.Sikap ilmiah mahasiswa merupakan skor pencapaian indikator sikap ilmiah pada rubrik peer assessment yang meliputi kedisiplinan, kejujuran, ketelitian atau kecermatan, dan kerja keras atau kesungguhan dalam menyusun laporan praktikum individu tentang fotosintesis.

Hasil kerja praktikum yang dimaksud berupa laporan praktikum individu mengenai fotosintesis yang disusun secara sistematis meliputi judul, tujuan, dasar teori, alat dan bahan, cara kerja, hasil pengamatan, pembahasan, kesimpulan, dan daftar pustaka.

Instrumen yang digunakan dalam penelitian ini adalah format analisis pelaksanaan pemanfaatan jejaring facebook dalam peer assessment online, rubrik penilaian peer assessment yang dilakukan secara online dengan memanfaatkan jejaring facebook untuk mengungkap aspek-aspek sikap ilmiah mahasiswa seperti disiplin, teliti/cermat, jujur, dan kerja keras (kesungguhan) pada hasil kerja praktikum (laporan praktikum), angket dan pedoman wawancara.

Untuk data yang berupa jawaban kuesioner yang diberikan kepada 40 mahasiswa kemudian dianalisis. Data yang diperoleh dari pertanyaan yang terdapat pada lembar angket berupa data kualitatif, agar data tersebut dapat diukur, maka diadakan transformasi dari data kualitatif menjadi data kuantitatif dengan cara memberikan skor pada setiap jawaban soal tersebut.

Dalam pengukuran data, peneliti menggunakan sistem kategori menggunakan skala sebagai berikut. Pemberian skor dilakukan dengan ketentuan sebagai berikut:

a) Alternatif jawaban sangat setuju diberi skor 4

b) Alternatif jawaban satuju diberi skor 3

c) Alternatif jawaban tidak setuju diberikan skor 2

d) Alternatif jawaban sangat tidak setuju diberikan skor 1

Dengan meniadakan ragu-ragu atau netral sebagai jawaban. Skala tersebut menggunakan hanya item yang secara pasti baik dan secara pasti buruk, tidak dimasukkan yang agak baik, yang agak kurang dan yang netral.

\section{Hasil dan Pembahasan}

Kegiatan peer assessment online diawali dengan memberikan informasi lengkap tentang kegiatan yang akan dilakukan oleh mahasiswa dan memberikan penjelasan bahwa kegiatan tersebut sangat penting. Hal ini karena melalui kegiatan peer assessment online mahasiswa mampu menunjukkan sifat objektif untuk menilai teman sejawat sesuai dengan fakta yang ada dilapangan. Selaian itu pemberian motivasi juga dilakukan secara langsung di kelas agar mahasiswa bersemangat mengikuti kegiatan tersebut. Selain itupemberian informasi dan motivasi juga dilakukan secara tidak langsung dengan mengirimkan notes ke alamat facebook setiap mahasiswa yang berisi tentang penjelasan singkat mengenai tujuan, keuntungan, dan manfaat dari peer assessment online dengan memanfaatkan facebook.

Sebanyak 95\% atau hampir seluruh mahasiswa antusias dalam melaksanakan peer assessment online karena kegiatan ini belum pernah mereka lakukan sebelumnya. Hal ini dapat dilihat dari format pelaksanaan peer assessment online dan juga obsrvasi langsung serta angket yang sudah dibagikan kepada mahasiswa. Data selengkapnya dapat dilihat pada grafik di bawah ini.

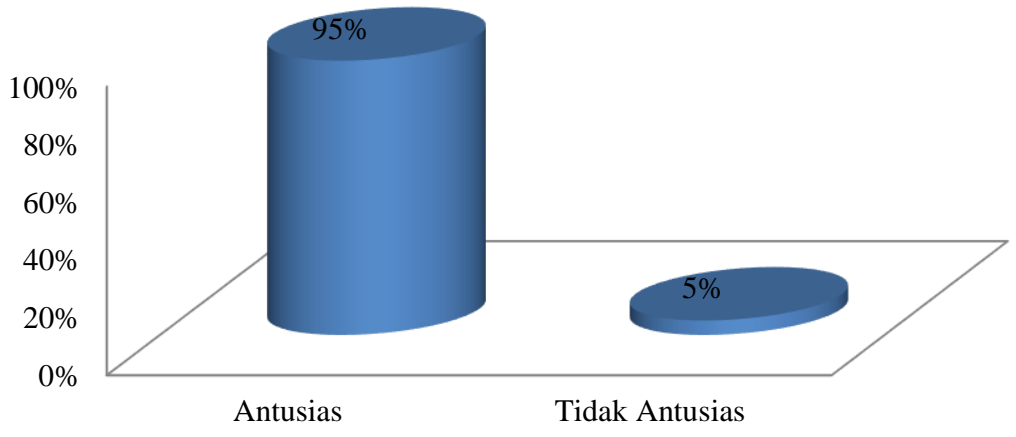




\section{Gambar 1. Grafik Antusias Mahasiswa dalam Mengikuti Kegiatan Penilaian Sikap Menggunakan Media Sosial Facebook}

Grafik di atas menunjukkan bahwa pelaksanaan peer assesment online dengan memanfaatkan jejaring facebook sangat disukai oleh mahasiswa, karena sebanyak 38 mahasiswa atau 95\% dari jumlah keseluruhan mahasiswa sangat antusias dalam mengikuti kegiatan ini. Pelaksanaan peer assesment onlinedapat dilakukan mulai dari tahap memotivasi mahasiswa, negosiasi kriteria penilaian, latihan peer assement online, pelaksanaan peer assesment online, komunikasi hasil peer assement online, sampai pemberian feedback (umpan balik).

Dari data yang diperoleh, terungkap bahwa kegiatan peer assement online dapat digunakan untuk menilai sikap ilmiahnya. Hal ini dapat dilihat dari data di bawah ini.

Tabel 1. Rekapitulasi Data Hasil peer assesment Mengguanakan facebookuntuk menilai Sikap Ilmiah Mahasiswa pada Mata Kuliah Praktikum Sains Inovatif

\begin{tabular}{lcc}
\hline \multicolumn{1}{c}{ Aspek } & Jumlah & $\begin{array}{c}\text { Persentase } \\
(\boldsymbol{\%})\end{array}$ \\
\hline Sikap ilmiah yang terungkap & 35 & 87,5 \\
Sikap ilmiah tidak terungkap & 5 & 12,5 \\
Total & 40 & 100 \\
\hline
\end{tabular}

Sebanyak 35 mahasiswa atau 87,5\% dari keseluruhan mahasiswa (40 orang) yang dapat ternilai sikap ilmiahnya. Sehingga pemanfaatan jejaring facebook dalam peer assessment online dapat menilai sebagian besar sikap ilmiah mahasiswa pada hasil kerja (laporan) praktikum. Sebanyak 12,5\% mahasiswa lainnya tidak terungkap atau ternilai sikap ilmiahnya melalui peer assessment online dengan memanfaatkan jejaring facebook, dikarenakan masalah teknis dan non teknis.

Setelah diberikan feedback oleh dosen pengampu mata kuliah terhadap mahasiswa, diketahui bahwa sebanyak 92,5\% mahaiswa mau merubah sikap ilmiahnya sedangkan sisanya tidak mau. Data selengkapnya dapat dilihat pada Gambar 2. di bawah ini

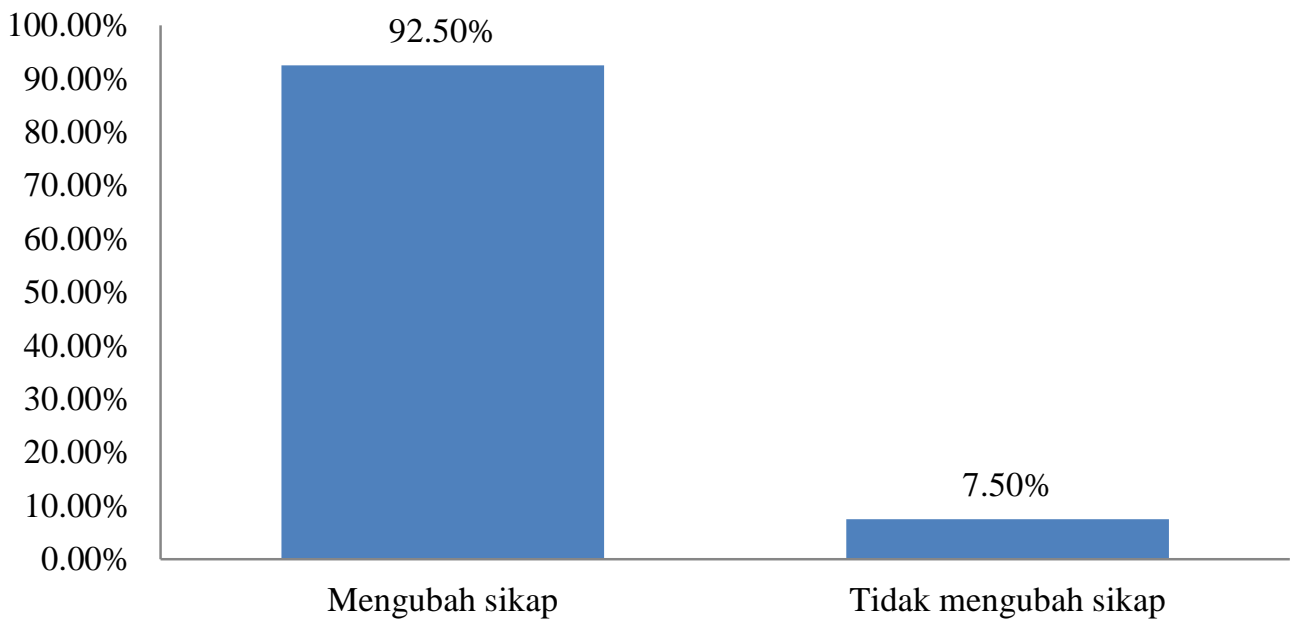

\section{Gambar 2. Grafik Peningkatan Sikap Ilmiah Mahasiswa STKIP Citra Bakti}

Setelah melakukan peer assessment online dengan memanfaatkan jejaring facebook, tanggapan terhadap kegiatan ini sangat beragam, dari angket yang diberikan yaitu menanyakan suka dan setuju terhadap penggunaan jejaring facebook untuk menilai sikap ilmiah mahasiswa, diperoleh data seperti digambarkan pada grafik di bawah ini. 


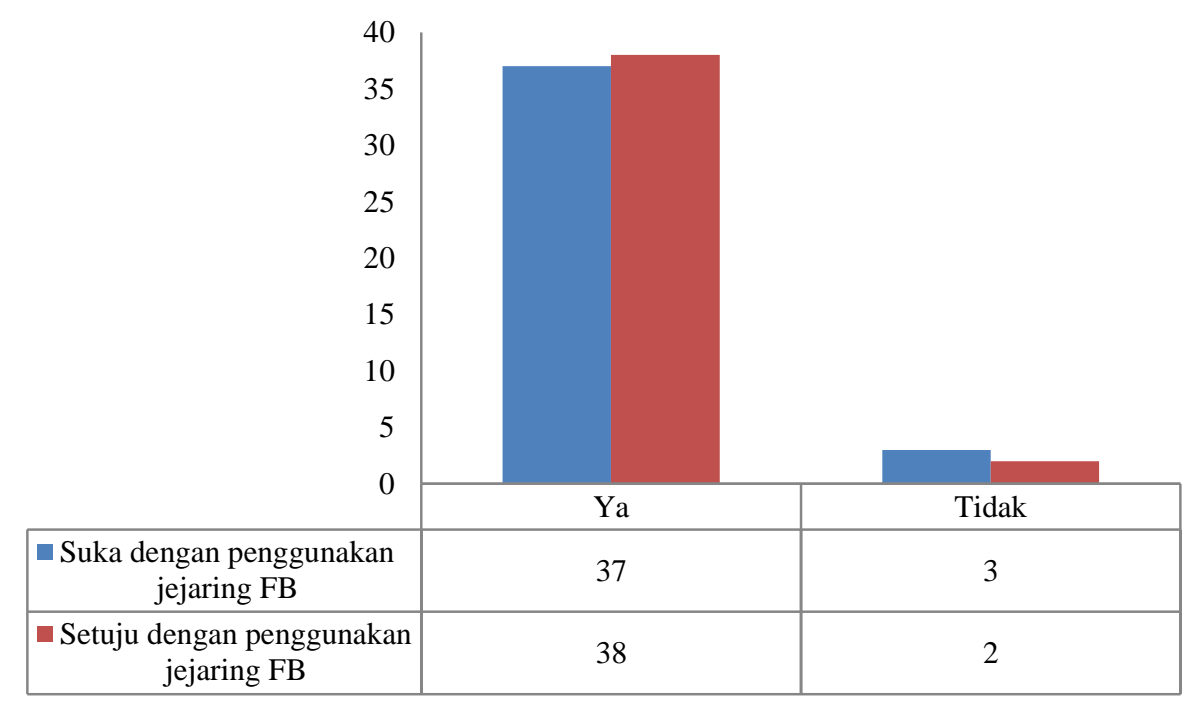

\section{Gambar 3. Grafik Tanggapan Mahasiswa (Suka dan Setuju) Penggunaan Jejaring Facebook untuk Mengukur Sifat Ilmiah}

Sebanyak 37 orang mahasiswa menyatakan suka menggunakan media facebook untuk menilai sikap ilmiah teman sejawatnya dan sebanyak 38 orang mahasiswa menyatakan setuju dengan penggunakan media facebook untuk menilai sikap ilmiah teman sejawatnya. Jadi secara umum mahasiswa sangat suka dan setuju menggunakan media facebook untuk diterapkan didalam proses perkuliahan terutama perkuliahan praktikum untuk menilai sikap ilmiah mahasiswa.

Melihat pentingnya penguasaaan sains dalam peningkatan mutu sumber daya manusia dan manfaatnya dalam kehidupan sehari-hari, maka sudah sewajarnya sains harus menjadi perhatian penting. Dinatha (2017) menyatakan bahwa tingkat kesulitan belajar sains (IPA) masih sedang, karena banyak faktor yang memengaruhinya. Hal ini tentu menjadi perhatian penting di masa yang akan datang. Proses belajar yang baik akan memberikan hasil belajar yang baik pula. Proses belajar sains menekankan pada pembelajaran saintifik agar memperolah hasil belajar yang baik (Upayogi, 2017).

Hasil belajar menurut Bloom (1976) mencakup prestasi belajar, kecepatan belajar, dan hasil afektif. Andersen (1981) sependapat dengan Bloom bahwa karakteristik manusia meliputi cara yang tipikal dari berpikir, berbuat, dan perasaan. Tipikal berpikir berkaitan dengan ranah kognitif, tipikal berbuat berkaitan dengan ranah psikomotor, dan tipikal perasaan berkaitan dengan ranah afektif. Ranah afektif mencakup watak perilaku seperti perasaan, minat, sikap, emosi, atau nilai. Ketiga ranah tersebut merupakan karakteristik manusia sebagai hasil belajar dalam bidang pendidikan.

Menurut Popham (1995), ranah afektif menentukan keberhasilan belajar seseorang. Orang yang tidak memiliki minat pada pelajaran tertentu sulit untuk mencapai keberhasilan belajar secara optimal. Seseorang yang berminat dalam suatu mata pelajaran diharapkan akan mencapai hasil pembelajaran yang optimal. Oleh karena itu semua pendidik harus mampu membangkitkan minat semua peserta didik untuk mencapai kompetensi yang telah ditentukan. Selain itu ikatan emosional sering diperlukan untuk membangun semangat kebersamaan, semangat persatuan, semangat nasionalisme, rasa sosial, dan sebagainya. Untuk itu semua dalam merancang program pembelajaran, satuan pendidikan harus memperhatikan ranah afektif.

Keberhasilan pembelajaran pada ranah kognitif dan psikomotor dipengaruhi oleh kondisi afektif peserta didik. Peserta didik yang memiliki minat belajar dan sikap positif terhadap pelajaran akan merasa senang mempelajari mata pelajaran tertentu, sehingga dapat mencapai hasil pembelajaran yang optimal. Walaupun para pendidik sadar akan hal ini, namun belum banyak tindakan yang dilakukan pendidik secara sistematik untuk meningkatkan minat peserta didik. Oleh karena itu untuk mencapai hasil belajar yang optimal, dalam merancang program pembelajaran dan kegiatan pembelajaran bagi peserta didik, pendidik harus memperhatikan karakteristik afektif peserta didik.

Pengukuran aspek afektif (sikap) khususnya sikap ilmiah biasa dilakukan melalui skala sikap. Adapun cara yang dilakukan adalah dengan cara peer assessment onlinemenggunakan media sosial facebook. Dari hasil penelitian yang dilakukan kepada 40 mahasiswa di STKIP Citra Bakti Ngada, diketahui bahwa 95\% dari seluruh jumlah mahasiswa yang melakukan kegiatan ini sangat antusias. Hal ini karena kegiatan ini pertama kali dilakukan dan melibatkan mahasiswa secara langsung serta menggunakan media sosial dalam proses pelaksanaannya. Sebanyak 35 mahasiswa atau 87,5\% dari keseluruhan mahasiswa (40 orang) yang dapat ternilai 
sikap ilmiahnya. Sehingga pemanfaatan jejaring facebook dalam peer assessment online dapat menilai sebagian besar sikap ilmiah mahasiswa pada hasil kerja (laporan) praktikum. Sebanyak 12,5\% mahasiswa lainnya tidak terungkap atau ternilai sikap ilmiahnya melalui peer assessment online dengan memanfaatkan jejaring facebook, dikarenakan masalah teknis dan non teknis.

Permasalahan teknis yang dihadapi dalam kegiatan ini adalahproses lama (loading), menjadi salah satu penyebab tidak seluruh mahasiswa terungkap sikap ilmiahnya. Hal ini karena banyak mahasiswa yang mengunakan jaringan internet secara serantak, sehingga jaringan internet menjadi kurang stabil. Hal ini berdampak pada loading yang lama dan halama facebook tidak dapat dibuka.Selain itu permasalahan juga timbul, yaitu selain membuka facebook, mahasiswa juga membuka situs yang lain dan memperparah system jaringan internet yang ada. Masalah teknis tersebut menyebabkan mereka tidak antusias untuk melaksanakan peer assessment online. Hal ini tentu saja dapat dimaklumi karena menurut Azwar (2009) pengalaman buruk yang dialami oleh seseorang pada suatu objek akan membentuk sikap negatif terhadap objek tersebut.

Kekurangaktifan mahasiswa dalam mengakses akun facebook-nya menjadi penyebab tidak seluruh mahasiswa terungkap sikap ilmiahnya. Kekurangaktifan tersebut kemungkinan disebabkan sudah tidak tertarik lagi untuk mengakses akun facebook atau merasa tidak suka dengan kegiatan peer assessment online melalui jejaring facebookkarena faktor-faktor seperti kecepatan akses internet, kebosanan dan lain-lain.Berdasarkan hasil angket sebanyak37 orang mahasiswa atau sebagian besar mahasiswa yang menyukai kegiatan peer assessment online melalui jejaring facebook ini seperti yang tertuang dalam Gambar 2. Sedangkan sebanyak 3 orang mahasiswa tidak setuju dan menyukai kegiatan ini karena faktor kecepatan internet dan kebosanan. Sebagaimana menurut Azwar (2009) bahwa aspek emosi atau komponen afektif seperti perasaan suka atau tidak suka merupakan salah satu komponen yang menyusun struktur sikap seseorang terhadap suatu objek.

Hasil penilaian sikap ilmiah secara peer assessment online tersebut dikomunikasikan secara tertulis oleh guru kepada seluruh mahasiswa melalui facebook message. Berdasarkan hasil angket sejumlah $92 \%$ mahasiswa atau hampir seluruh mahasiswa berencana untuk meningkatkan sikap ilmiah mereka. Hal ini senada dengan pernyataan Zulharman (2007) bahwa melalui peer assessment mahasiswa dapat menerima feedback atau masukan (kritik dan saran) dari orang lain.

Penggunaan facebook message untuk mengkomunikasikan hasil penilaian secara tertulis dinilai sangat memudahkan dan dapat menjaga kerahasiaan. Hal ini didukung oleh fitur facebook message yang hanya dapat dibuka oleh pemilik akun saja. Berdasarkan penelitian yang telah dilakukan pelaksanaan peer assessment online dengan memanfaatkan facebook memiliki kelebihan dan kekurangan. Jejaring facebook dapat dimanfaatkan dalam peer assessment untuk menghemat penggunaan waktu. Fitur-fitur dalam facebook mudah digunakan oleh penggunanya. Mahasiswa terlihat lebih bebas dalam mengeluarkan pendapatnya di facebook saat diskusi kriteria penilaian dibandingkan di dalam kelas. Hal ini didukung oleh hasil pengisian angket Mahasiswa yang berkaitan dengan kebebasan dalam melakukan peer assesment online melalui jejaring facebook, yaitu sebanyak $84 \%$ mahasiswa merasa bebas dalam proses pelaksanaan peer assessment online melalui jejaring facebook ini. Kebebasan ini maksudnya mereka merasa nyaman selama proses peer assessment online dan keleluasaan dalam hal waktu. Mulai tahun 2009 jejaring facebook mulai bisa diakses melalui mobile phone (Perambahan, 2009). Perkembangan ini sangat membantu dalam kegiatan peer assessment online. Mahasiswa dapat menilai hasil pekerjaan temannya dimana pun, misalnya di sekolah (saat istirahat), di kendaraan, di rumah, dan sebagainya. Keleluasaan waktu dan kemudahan yang ditawarkan oleh facebook ini yang membuat 37 mahasiswa atau 92,5\% dari seluruh jumlah mahasiswa menyatakan suka dengan kegiatan peer assessment online melalui jejaring facebook. Hal serupa diungkapkan pula oleh Yuwanisa (2010) bahwa pemanfaatan facebook sebagai media pembelajaran digandrungi atau disukai oleh para mahasiswa karena melalui facebook tersebut mereka dapat belajar sambil bersenang-senang.

Selain keleluasaan waktu dan kemudahan penggunaan fitur facebook, tarif biaya yang relatif rendah dalam mengakses facebook pun menjadi kemudahan dalam pemanfaatan jejaring facebook untuk peer assessment ini. Hasil angket menunjukkan sebanyak 95\%mahasiswa setuju dengan pemanfaatan jejaring facebook dalam peer assesment online. Hal ini terjadi karena melalui pemanfaatan jejaring facebook dalam peer assessment online ini tidak memberikan kerugian apa pun pada mahasiswa. Selain itu, hal ini sesuai dengan karakteristik seseorangyang biasanya menyukai hal-hal yang baru dalam proses pencarian jati dirinya.

\section{Simpulan}

Berdasarkan hasil penelitian dan pembahasan, maka dapat disimpulkan bahwa sebanyak $95 \%$ mahasiswa antusias dalam mengikuti kegiatan peer assessment online menggunakan jejaring facebook. Sebanyak $87,5 \%$ sikap ilmiah mahasiswa dapat dilihat dan dinilai dan sebanyak 92,5\% mahasiswa mau mengubah sikap ilmiahnya. Secara umum pemanfaatan jejaring facebook dalam peer assessment online untuk menilai sikap ilmiah mahasiswa dapat dilaksanakan. Namun, beberapa kendala teknis dan non teknis yang terjadi adalah terganggunya jaringan internet yang menyebabkan sulit atau bahkan gagal (error) untuk mengakses akun facebook, kekurangaktifan mahasiswa dalam mengakses akun facebook tersebut, sedangkan 
beberapa kelebihannya, yaitu keleluasaan waktu, biaya yang relatif rendah, bebas dan nyaman ketika melakukan penilaian.

\section{Daftar Pustaka}

Andersen, L. M. (1981). Assessing Affective Characteristic in the Schools. Boston: Allyn\&Bacon

Azwar, S. (2009). Sikap Manusia Teori dan Pengukurannya. Yogyakarta. Pustaka Pelajar.

Bloom, B.S. (1976). Human Characteristics and School Learning. New York: McGraw Hill Book Co.

Depdiknas. (2008). Kriteria dan Indikator Keberhasilan Pembelajaran. Jakarta. Depdiknas.

Dinatha, N.M. (2017). Kesulitan Belajar Siswa dalam Mata Pelajaran IPA Terpadu. Jurnal Pendidikan Dasar Nusantara. 2 (2): 214-223

Musfiqon. (2012). Pengembangan Media dan Sumber Media Pembelajaran. Jakarta: PT. Prestasi Pustakaraya.

Perambahan, A. (2009). Facebook Data dan Fakta Sejarah. http://www.asalusul. com/2009/03/facebook-datadanfakta-sejarah.html. Diakses tanggal 14 Juli 2017.

Popham. W. (1995). Clasroom Assesment What Teacher Need to Know. Boston: Simon\&Schuster Company.

Rustaman, N.Y., dkk. 2003. Strategi Belajar Mengajar Biologi. Jurusan Pendidikan Biologi FPMIPA UPI.

Soehartono, I. (2000). Metode Penelitian Sosial. Bandung. Rosda. Sugiyono. 2010. Metode Penelitian Pendidikan Pendekatan Kuantitatif, Kualitatif, dan R\&D. Bandung.

Susianna, N. (2008). Program Pembelajaran Kimia Untuk Menumbuhkan Sikap Wirausaha Siswa SMA.http://puslitjaknov.org/data/file/2008/makalah_peserta/38_Dr.\%20Nancy\%20Susiana,\%20MPd_ \%20Program\%20Pembelajaran\%20Kimia.pdf. Diakses tanggal 11 Juli 2017.

Tsauri, A.S. (2010). Fenomena Facebook di Dunia Pendidikan Kita. http://tsauri28.myhaley.com/blog/ fenomena-facebook-di-duniapendidikankita/. Diakses tanggal 19 Maret 2010.

Upayogi, I. N. T. (2017). Peningkatan Kemampuan Guru menerapkan Pendekatan Saintifik Melalui Lesson Study. Jurnal Pijar Nusantara. 2 (2): 103-113.

Yuwanisa, A. (2010). Facebook Sebagai Media Pendukung Pembelajaran Siswa.http://suaramerdeka.com/ v1/index.php/read/news/2010/02 /08/46477/Facebook-Media- Pendukung-Pembelajaran- Siswa. Diakses tanggal 16 Juli 2017.

Zulharman. (2007). Self dan Peer Assessment Sebagai Penilaian Formatif dan Sumatif. http://zulharman79.wordpress.com/2007/05/29/self-dan-peerassessmentsebagaipenilaianformatifdansumatif/. Diakses tanggal 14 Juli 2017. 